\title{
Vehicle Emission Factors for Particulate and Gaseous Pollutants in an Urban Tunnel in Xi'an, China
}

\author{
Danting Zhao $(D$, Hong Chen $(D$, Haipeng Shao, and Xiaoke Sun \\ Department of Traffic Engineering, Chang'an University, Xi'an 710064, China \\ Correspondence should be addressed to Hong Chen; hongchen82@126.com
}

Received 7 March 2018; Revised 31 May 2018; Accepted 21 June 2018; Published 10 July 2018

Academic Editor: Antonio De Lucas-Consuegra

Copyright ( 2018 Danting Zhao et al. This is an open access article distributed under the Creative Commons Attribution License, which permits unrestricted use, distribution, and reproduction in any medium, provided the original work is properly cited.

Urban tunnels are generally used to measure traffic-related particles and gas pollutant concentrations. To understand on-road vehicle emissions and update emission factors (EFs), traffic volume data and emissions of particulate matter smaller than $2.5 \mu \mathrm{m}$ $\left(\mathrm{PM}_{2.5}\right)$, carbon monoxide $(\mathrm{CO})$, nitrogen oxides $\left(\mathrm{NO}_{X}\right)$, hydrocarbon $(\mathrm{HC})$, and volatile organic compounds (VOCs) for mixed vehicles were investigated at the Wenchang Gate-Peace Gate Tunnel in Xi' an over 11 days. An average fleet of 14,199 vehicles with mean speeds that ranged from $18 \mathrm{~km} \cdot \mathrm{h}^{-1}$ to $46 \mathrm{~km} \cdot \mathrm{h}^{-1}$ passed through the tunnel during the sampling period each day. A mass balance model and linear regression analysis were adopted to derive pollutant EFs for mixed vehicles, cars, and taxis, respectively. The results demonstrated that EFs during the night were higher than those during the day because goods vehicles are only allowed to travel from 22:00 to 07:00. Averaged EFs of $\mathrm{PM}_{2.5}, \mathrm{CO}, \mathrm{NO}_{X}, \mathrm{HC}$, and VOCs for the total fleet were $0.006 \pm 0.005,1.097 \pm 0.398$, $0.159 \pm 0.092,0.179 \pm 0.089$, and $0.317 \pm 0.172 \mathrm{~g} \cdot \mathrm{veh}^{-1} \cdot \mathrm{km}^{-1}$, respectively, lower than those reported from other literatures owing to the strict requirements of emission standards and improvements in vehicle technology. This method provides an approach to measure the EFs for different types of vehicles in urban traffic and evaluate traffic pollution in distinct areas.

\section{Introduction}

Vehicle exhaust is a threat to both the living environment and human health [1]. Emissions of particulate and gaseous pollutants from exhaust pipes in motor vehicles, tire and brake wear, and dust on the road have become important contributors to air pollution [2]. Most cities are subject to severe smog pollution whose main composition is fine particles such as particulate matter smaller than $2.5 \mu \mathrm{m}\left(\mathrm{PM}_{2.5}\right)$ during winter and ozone pollution whose primary precursors are nitrogen oxides $\left(\mathrm{NO}_{X}\right)$ and volatile organic compounds (VOCs) during summer [3-5]. Pollutants reduce visibility resulting in an increase in the risk of traffic accidents $[6,7]$. In addition, vehicle emissions have adverse impacts on health according to epidemiological studies [8]. During recent years, many metropolis cities have implemented vehicle restriction policies in which some types of vehicles are not allowed at certain times or must travel on required roads [9]. In Xi'an, a midwestern city in China, goods vehicles are forbidden to travel inside the Second Ring Road during the day considering environmental quality and traffic safety. Moreover, beginning in 2016, on-road vehicles except public transportation are limited by license number during the weekdays during winter when the smog is serious on the basis of the air quality index forecast, while during weekends and holidays, there are no limitations. For example, vehicle tail numbers of 1 and 6 are restricted on Monday if the forecast shows air quality would be mild pollution, and an odd-even car ban could be applied when a red alert for air pollution is issued by the government. The purpose of the aforementioned policies and measurements is to reduce traffic-related air pollution. These measures all rely on accurate studies of emission factors (EFs) and corresponding emission inventories [10].

EFs refer to the emitted mass of pollutant per driven distance per vehicle and can be defined for a fleet as well as single vehicle [11]. Various techniques have been applied to measure EFs, and these can be classified into three categories: laboratory tests, on-road measurements, and model simulations. Chassis dynamometer methods were initially the most popular laboratory tests [12]. A single vehicle under standard 
driving cycles in laboratories is used to obtain tailpipe emissions. However, emissions of a traffic fleet are difficult to test because of the high expense, and real-world traffic conditions are too complex to simulate [13]. Real-time and on-road emission measurements that reflect the real conditions of traffic include single vehicle on-road cycles, remote sensing, and tunnel measurement [14]. Single vehicle on-road cycles are usually equipped with measuring facilities such as an emission analyzer, portable emissions measurement systems (PEMS), and Global Positioning System (GPS) in the testing vehicle, and then the vehicle is driven along a designated road to measure emissions and speed $[15,16]$. Nevertheless, the cost is high if too many vehicles are involved, and the result is also related to a driver's behavior. Remote sensing is applied to evaluate gaseous pollutants, while particulate matter is difficult to investigate [17]. Tunnel measurement has its advantages in studying a real-world fleet of vehicles by monitoring pollutant concentrations as well as meteorological and traffic parameters at the inlet and outlet of an urban tunnel [18]. The differences in concentrations between the two sites are considered as the emissions from mobile sources in the tunnel where ventilation is closed. Moreover, mass balance model or carbon mass balance is often used to estimate EFs $[19,20]$. Compared to other methods, a tunnel test is more accurate in measuring average EFs that represent the comprehensive level of urban traffic [21]. Furthermore, new techniques have been developed in using simulated EF models such as MOBILE, COPERT, IVE, CEME, and MOVES [22, 23]. These models have been established by European and American researchers, and the EFs can be obtained directly by inputting the required data such as vehicle type, age distribution, driving distance, and ambient temperature $[24,25]$. To apply these models well and meet the needs of practical conditions, some parameters need to be localized, particularly for an area in China. Therefore, it was assumed that tunnel measurement is a basic method to compare and correct the results of estimated EF models, and it is still necessary to do so.

Vehicle EFs are different in distinct areas at different times and change all the time because of many dynamic factors, such as road characteristics (tunnel dimensions, structure, and gradient), traffic conditions (traffic volume, fleet speed, vehicle type, and age), vehicle performance (engine, fuel, and accumulating mileage), driving behavior (acceleration and deceleration), environmental factors (temperature, wind speed, and pressure), and emission standards. All of the aforementioned result in dramatic changes in EFs, and therefore, it is important to update EFs to reflect the real emission situation of an area.

During recent years, many cities have conducted EF studies. The types of vehicles were mainly classified into lightduty vehicles and heavy-duty vehicles [26]. Nevertheless, few researchers have focused on cars and taxis because goods vehicles are limited in numerous cities during the day such that the major vehicles on the roads were these two types and public transport. In addition, the only tunnel test conducted in Xi'an, China, was undertaken in 1996 [27], and there has been no further study in the city since. The EFs must have changed because of the increasing number of vehicles and the different emission standards of today. This study aimed to measure traffic-related pollutants in the Wenchang GatePeace Gate Tunnel and update the average EFs of $\mathrm{PM}_{2.5}$, carbon monoxide (CO), $\mathrm{NO}_{X}$, hydrocarbon ( $\mathrm{HC}$ ), and VOCs for the total fleet, cars, and taxis in Xi'an. The results not only present the latest vehicle emission conditions in Xi'an but also provide a sound reference for traffic pollutant assessments and policymaking for the government.

\section{Materials and Methods}

2.1. Tunnel Description. The Wenchang Gate-Peace Gate Tunnel consists of two unidirectional bores that are $992 \mathrm{~m}$ in length and that have no internal curves. Both bores have two lanes with one entrance and one exit. The posted speed limit is $50 \mathrm{~km} \cdot \mathrm{h}^{-1}$. The tunnel is on Ring Road in the Beilin District and is also the longest urban tunnel in Xi'an, China. The tunnel is a direct transportation link between the Wenchang Gate and Peace Gate as well as the main road access to the City Wall which is the center of Xi'an. Restricted by policy, goods vehicles are not allowed in the tunnel from 07:00 to 22:00.

In general, there is a ventilation system in the tunnel to supply fresh air; however, to avoid the effect of ventilation, the vent pipes were all closed during our tests, such that the condition of the tunnel could only be considered a result of traffic-induced pistons and natural forces. Similarly, ambient air pollutants were generated only by the vehicles.

2.2. Measurements. The main vehicle of the traffic fleet in the urban tunnel was gasoline car of which most emissions were $\mathrm{PM}_{2.5}, \mathrm{CO}$, and $\mathrm{NO}_{X}$ [28]. Thus, two on-road monitoring points were set $200 \mathrm{~m}$ from the inlet and outlet with a crosssectional area of $39 \mathrm{~m}^{2}$ and a height of $1.5 \mathrm{~m}$ above the platform inside the eastbound bore as shown in Figure 1. The pollutants $\mathrm{PM}_{2.5}, \mathrm{CO}, \mathrm{NO}_{X}$, and $\mathrm{HC}$ (including methane and nonmethane total hydrocarbons) and VOCs (including nonmethane total hydrocarbons, benzene, toluene, and xylene) were measured in the Wenchang Gate-Peace Gate Tunnel simultaneously in this study. Sampling occurred from July 17 to July 27, 2015 (including seven weekdays, two Saturdays, and two Sundays). Considering the number and functions of the measuring devices, as well as the different concentrations between inlet and outlet, the devices at sampling sites 1 and 2 were not exactly the same in terms of the accuracy of the tests, as summarized in Table 1.

Measuring devices were used to acquire particulate pollutant $\mathrm{PM}_{2.5}$ and gaseous pollutants $\left(\mathrm{CO}, \mathrm{NO}_{X}, \mathrm{HC}\right.$, and VOCs). The sampling periods were split into morning transit (07:00-10:00), afternoon period (12:00-15:00), evening transit (17:00-20:00), and night period (22:00-24:00). A TSI Q-Trak was used for probing the ambient temperature, relative humidity, barometric pressure, and air velocity (V). Additionally, a video camera was installed at the exit at the same time to record traffic data. The traffic volume and the number of different types of vehicles were manually counted every 15 min from video tapes directly such that the hourly average indexes were calculated. The types of vehicles were classified into five major categories, namely, cars, taxis, buses (including 


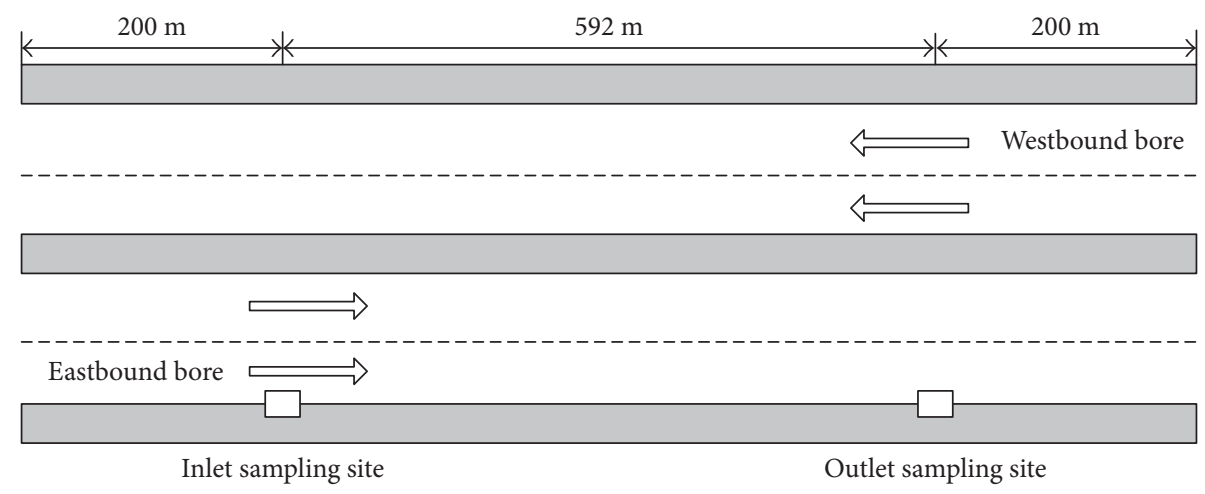

Figure 1: Sampling sites in the tunnel. The inlet sampling site was set $200 \mathrm{~m}$ from the inlet, and the outlet sampling site was set $200 \mathrm{~m}$ from the outlet in the eastbound bore.

TABLE 1: Measuring devices in the tunnel.

\begin{tabular}{|c|c|c|c|c|c|}
\hline & Device at site 1 & Device at site 2 & $\begin{array}{l}\text { Company, } \\
\text { country }\end{array}$ & $\begin{array}{l}\text { Time } \\
\text { resolution }\end{array}$ & Technical parameter \\
\hline $\mathrm{PM}_{2.5}$ & \multicolumn{2}{|c|}{$\mathrm{E}-\mathrm{BAM}\left(\mathrm{PM}_{2.5}\right)$} & $\begin{array}{l}\text { Met One, } \\
\text { USA }\end{array}$ & $1 \mathrm{~min}$ & $0-10 \mathrm{mg} \cdot \mathrm{m}^{-3} ; 2.5 \mu \mathrm{g}$ \\
\hline $\mathrm{CO}$ & Thermo $48 \mathrm{i}(\mathrm{CO})$ & Ecotech 9830 & $\begin{array}{l}\text { Ecotech, } \\
\text { Australia }\end{array}$ & $1 \mathrm{~min}$ & 0-200 ppm; $0.1 \mathrm{ppm}$ \\
\hline $\mathrm{NO}_{X}$ & $\begin{array}{l}\text { Airbags, Interscan } \\
\qquad\left(\mathrm{NO}_{X}\right)\end{array}$ & Ecotech 9841B & $\begin{array}{l}\text { Ecotech, } \\
\text { Australia }\end{array}$ & $5 \mathrm{~min}$ & $0-100$ ppm; 1 ppb \\
\hline $\mathrm{HC}$ & Airbags & $\begin{array}{l}\text { 55C Methane-NMHC } \\
\text { analyzer }\end{array}$ & Thermo, USA & $5 \mathrm{~min}$ & $0-50 \mathrm{ppm} ; 0.1 \mathrm{ppm}$ \\
\hline VOCs & \multicolumn{2}{|c|}{$\mathrm{PPb} \mathrm{RAE} 3000 \mathrm{VOC}$} & RAE, USA & $1 \mathrm{~min}$ & $1 \mathrm{ppb}-10000$ ppm; 1 ppb \\
\hline $\begin{array}{l}\text { Meteorological } \\
\text { parameters }\end{array}$ & \multicolumn{2}{|c|}{ Q-Trak, V-Trak 7575} & TSI, USA & $1 \mathrm{~min}$ & $\begin{array}{l}\text { TP: } 0-50^{\circ} \mathrm{C}, 0.1^{\circ} \mathrm{C} ; \mathrm{RH}: 5 \% \sim 95 \% \mathrm{rh} \text {, } \\
0.1 \% \text { rh; BP: } 0.1 \mathrm{kPa} ; \mathrm{V}: 0.1 \mathrm{~m} \cdot \mathrm{s}^{-1}\end{array}$ \\
\hline Traffic parameters & \multicolumn{2}{|c|}{ Camera, Simi-motion } & & Continuous & $1 \mathrm{~h} ; 0.01 \mathrm{~m} \cdot \mathrm{s}^{-1}$ \\
\hline
\end{tabular}

Note. VOCs were measured using PPB RAE in this study. The reported VOC was a relative value based on the VOC used to calibrate the instrument and thus was not comparable to the HC measurement.

public buses; coach buses; and light, medium, and heavy buses), goods vehicles (GVs) (including light, medium, and heavy goods vehicles), and others (including tricycles, motorcycles, and special cars such as ambulances and clean cars). Furthermore, the speed and acceleration of vehicles were obtained using the Simi-motion software indirectly.

2.3. Quality Control. $\mathrm{PM}_{2.5}$ was measured using an online method, and a beta-ray attenuation method was used in E-BAM. In this study, the cut particle size was $2.5 \mu \mathrm{m}$ and flow rate was $16.7 \mathrm{~L} \cdot \mathrm{min}^{-1}$. Examining the state of devices daily was necessary to ensure sound operation. More importantly, the work of downloading and data checking was carefully completed daily. Backup battery and the power contact of the instrument were checked regularly to avoid power outages.

For measurement of $\mathrm{CO}$, the devices must be fully warm and stable for $30 \mathrm{~min}$ prior to measurement. In addition, the fan filter was cleaned and the sampling filter was periodically replaced. The calibration points were divided into low range and high range, and each range consisted of three points $(80 \%, 50 \%$, and $20 \%$ of the range). The first was zero check; a test was conducted for at least $5 \mathrm{~min}$, the average time of the instrument was set at $300 \mathrm{~s}$ to obtain the best accuracy, and then a span check was conducted.
Similar precautions were taken for $\mathrm{NO}_{X}$ measurement. Adequate preheating, regular replacement of front filters, sintering the filter, and cleaning of the gas pipeline were necessary. A NO standard was used for calibration, and at least $10 \mathrm{~min}$ of zero air was needed.

As for measurement of HC, VOCs, and meteorological data, zero calibration was essential and the devices were started $15 \mathrm{~min}$ prior to sampling. Only when the devices were in a storage state and the operation was normal during the warm-up phase could the sampling start.

2.4. Emission Factors. The mass balance model is widely used to determine EFs in tunnels. Based on the principle of mass conservation, a tunnel is regarded as an ideal cylindrical piston, and the difference between the pollutants passing through the two sections is the total mass of pollutants between the two sections [29]. The model has two assumptions. First, except that the jet fan can accelerate the wind speed inside the tunnel, only one inlet and one outlet can be set; there are no other air inlets or outlets. Second, the measured contaminants cannot deposit, decompose, or transform during the sampling time. As a result, average EFs can be calculated as follows [30]: 


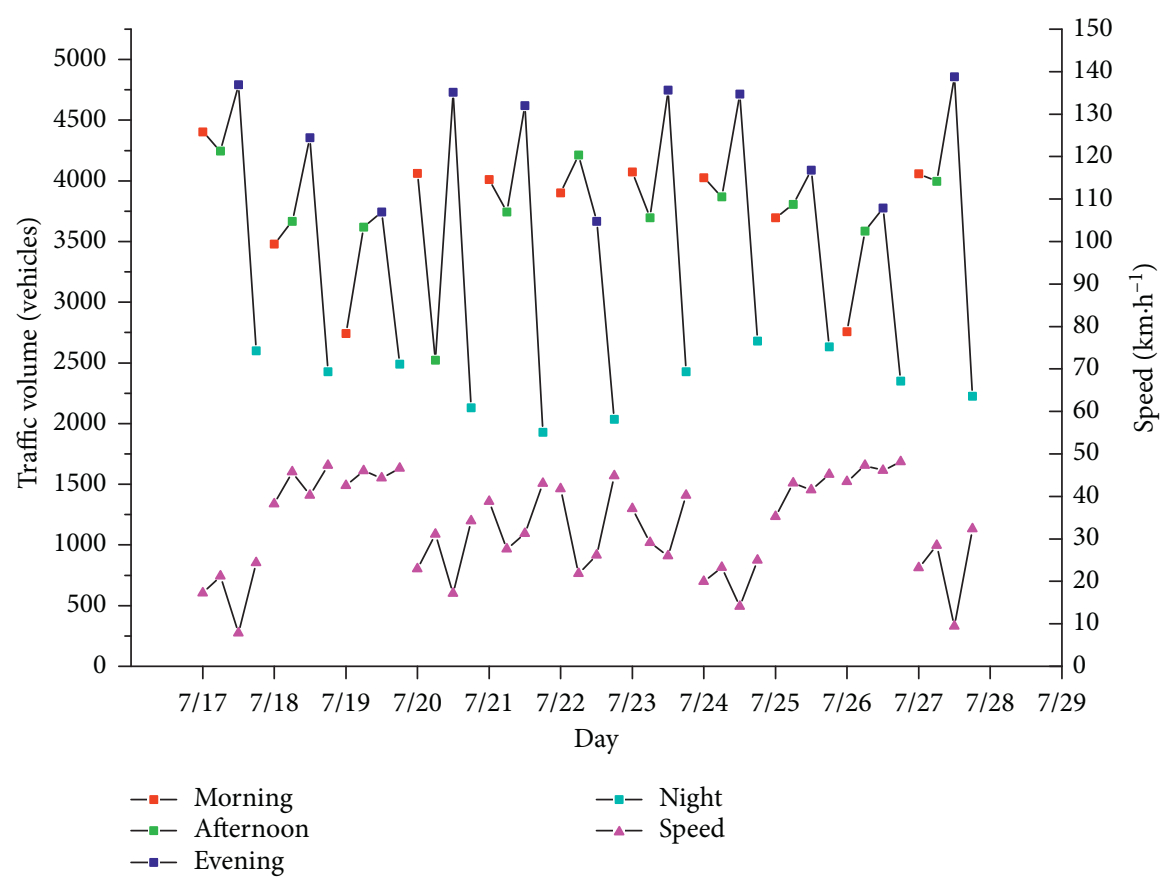

FIGURE 2: Diurnal variations in traffic volume and speed during the sampling period. Left axes show the number of vehicles during the morning transit (07:00-10:00), afternoon period (12:00-15:00), evening transit (17:00-20:00), and night period (22:00-24:00) from July 17 to July 27,2015 . The right axes show the corresponding average speed of the total fleets.

$$
\mathrm{EFs}=\frac{\left(C_{\text {outlet }}-C_{\text {inlet }}\right) \cdot V \cdot T \cdot A}{N \cdot L}
$$

where EFs $\left(\mathrm{mg} \cdot \mathrm{veh}^{-1} \cdot \mathrm{km}^{-1}\right)$ are the average emission factors for mixed vehicles; $C_{\text {outlet }}$ and $C_{\text {inlet }}\left(\mathrm{mg} \cdot \mathrm{m}^{-3}\right)$ are the concentrations of the pollutants at the outlet and inlet inside the tunnel, respectively; $V\left(\mathrm{~m} \cdot \mathrm{s}^{-1}\right)$ is the air velocity inside the tunnel; $T(\mathrm{~s})$ is the time interval; $A\left(\mathrm{~m}^{2}\right)$ is the cross-sectional area in the tunnel; $N$ (veh) is the number of vehicles; and $L$ $(\mathrm{m})$ is the length from the sampling inlet site to the outlet site.

Mean EFs reflect the level of pollutant emissions from all motor vehicles passing through the tunnel at different sampling times. They represent a combination of mean vehicle speed, vehicle type, age distribution, and mileage distribution. If the vehicles traveling within the tunnel could reflect the actual situation of traffic in a city, the calculated average EFs would represent the vehicles EFs in that area. Additionally, the average EFs for different types of vehicles can be calculated via linear regression [11]. In this study, the majority of vehicles were cars and taxis such that only these two types were considered in the calculation of EFs. The following equation can be used according to the linear regression model:

$$
\mathrm{EFs}=\sum_{i} \mathrm{EF}_{i} \cdot X_{i}
$$

where EFs are the average emission factors for mixed vehicles; $i$ is the different type of vehicles; $\mathrm{EF}_{i}\left(\mathrm{mg} \cdot \mathrm{veh}^{-1} \cdot \mathrm{km}^{-1}\right)$ is the emission factor for the vehicle $i$; and $X_{i}$ is the proportion for $i$.

\section{Results and Discussion}

3.1. Traffic Fleet Characteristics. Characteristics of the traffic fleets in the tunnel are related to traffic volume, fleet composition, and vehicle speed. In the eastbound bore where the sampling was conducted, 12,470-16,042 vehicles passed through the tunnel during the sampling periods per day. The traffic in this study presented distinct characteristics on workdays and weekends in that there was a higher volume on weekdays compared to that of weekends, as well as higher volume on Saturdays compared to that on Sundays. As for diurnal variations, the segmented traffic volume presented an $\mathrm{N}$-type distribution on workdays and an inverted U-type distribution on weekends, as shown in Figure 2. Moreover, the traffic fleets had two peaks termed tidal flow at the rush hours of 07:00-09:00 and 17:00-19:00 during workdays, while two peaks occurred at 11:00-13:00 and 18:00-20:00 on the weekends [21]. During weekdays, the flow of the morning transit on Monday and Friday was the highest; correspondingly, the return flows of the evening transit were also high. Additionally, the traffic at every sampling time on Friday was heavier, which may be because of regular working meetings, business travel, and entertainment. The common trend that the highest number of vehicles occurred during the evening rush hours may be explained in that the eastbound bore was an out-of-city direction, and the second highest traffic flow appeared during the morning. In contrast, the lowest volume was found during the night at approximately 23:00.

Because GVs are not allowed to enter the tunnel from 07: 00 to $22: 00$, GVs accounted for only approximately $0.6 \%$ of the total fleets while passenger vehicles accounted for $96.2 \%$, and in particular, cars had the highest proportion at approximately $80 \%$, and taxis were the second highest at $14 \%$. The GVs mainly traveled from Thursday to Sunday, particularly on weekends. Different weekday-weekend patterns were also reflected in the vehicle type. On average, there were 
TABLE 2: Mean mass concentrations of pollutants at the outlet and inlet.

\begin{tabular}{lcccc}
\hline Pollutants & $\begin{array}{r}\text { Inlet concentration } \\
\left(\mathrm{mg} \cdot \mathrm{m}^{-3}\right) \\
\text { Standard } \\
\text { deviation }\end{array}$ & Average & $\begin{array}{c}\text { Outlet concentration } \\
\left(\mathrm{mg} \cdot \mathrm{m}^{-3}\right)\end{array}$ \\
Average & $\begin{array}{c}\text { Standard } \\
\text { deviation }\end{array}$ \\
\hline $\mathrm{PM}_{2.5}$ & 0.048 & 0.023 & 0.054 & 0.023 \\
$\mathrm{CO}$ & 1.804 & 1.054 & 3.895 & 2.205 \\
$\mathrm{NO}_{X}$ & 0.544 & 0.111 & 0.694 & 0.099 \\
$\mathrm{HC}$ & 3.615 & 0.277 & 5.129 & 0.289 \\
VOCs & 0.324 & 0.082 & 0.441 & 0.149 \\
\hline
\end{tabular}

$5 \%$ more cars on workdays than on weekends, and more passengers chose taxis during the weekends.

To a large extent, the speed of the vehicles was inversely proportional to the traffic volume [31]. The more the vehicles in the tunnel, the slower the speed of the fleets. Similarly, the vehicle speed on weekends was higher than that on workdays, and the segmented traffic speed presented an N-type distribution from Friday to Monday and a U-type distribution from Tuesday to Thursday. Noticeably, the mean traffic volume during the morning was higher than that in the afternoon during the workdays; nevertheless, the average speed during the morning was not slower but faster compared to that of the afternoon during the same period. It was found that commuters during the weekday morning were hurrying to work, even if in a traffic jam, and the speed of driving was also faster than the afternoon when people were driving more leisurely. Moreover, the calculated time referred to the morning from 07:00-10:00, not only the peak hours, thus the average speed of the vehicles was slightly faster. Furthermore, the traffic flow during the afternoon on weekends was higher than that during the morning, and the speed had the same trend. This phenomenon may be attributed to trip purpose, including leisure and shopping during the weekend afternoon rather than working or business during the morning. The destinations were so dispersed that the operation of the traffic near the tunnel worked well during the afternoon even though there was a high volume.

3.2. Mass Concentrations of Pollutants. The mean mass concentrations of the pollutants at the outlet and inlet are presented in Table 2. It is obvious that the values at the outlets were higher than those at the inlets owing to the accumulation of the pollutants [32]. Average mass concentrations of $\mathrm{CO}$ and $\mathrm{HC}$ at the exit were 2.16 and 1.42 times those at the entrance, respectively, suggesting that the cars exhausted a considerable amount of $\mathrm{CO}$. Other pollutant mass concentrations at the exit were 1.13 to 1.36 times of those at the entrance.

Figure 3 demonstrates the variations in average mass concentrations at the outlet among different pollutants during the four sampling periods for 11 days. The pollutant mass concentrations were proportional to the traffic volume and inversely proportional to the fleet speed. It is shown that traffic volume had a distinct impact on pollutant concentrations. Moreover, a slower speed and a greater acceleration of vehicles resulted in a higher accumulation of pollutants [33]. All the curves show similar diurnal variations, with high values during the day and the highest occurring during the evening period (17:00-20:00) because of a great many vehicles in the evening rush hours. $\mathrm{PM}_{2.5}$ and $\mathrm{NO}_{X}$ concentrations had a similar trend with a correlation coefficient of 0.922 . HC and CO concentrations also had high correlation with a coefficient of 0.853 . However, the change rates in the $\mathrm{CO}$ and $\mathrm{HC}$ were higher than those of the other pollutants. This may be attributed to $\mathrm{CO}$ and $\mathrm{HC}$ mainly originating from cars and taxis, and the number of these types of vehicles during the night was significantly lower than that during the day, while the other pollutants were related to heavy-duty vehicles such as GVs that only operated in the tunnel during the night. The weekday-weekend pattern is shown in Figure 4. The average mass concentrations during weekends were lower than those during workdays, which was because of the lower volume and higher speed of the vehicles during the weekends. The concentrations during the night on weekends were higher than those during working days because of the high emissions of the GVs.

3.3. Average Emission Factors. The average EFs for the mixed vehicles during the different sampling periods are shown in Table 3. The night period had the highest values during the sampling time for the proportion of GVs. This comparison between the day and night suggests that the number of GVs is a decisive factor in the emissions of pollutants; most notably, the EFs of $\mathrm{PM}_{2.5}, \mathrm{NO}_{X}$, and VOCs during the night were nearly twice as high as those during the day. High EFs emerged during the evening during the daytime, corresponding well to a high traffic volume with a low fleet speed. In contrast, the values in the afternoon were the lowest because of the high speed and low volume. The gradient in the variation in $\mathrm{CO}$ and $\mathrm{HC}$ was greater than that in the other pollutants, which can be explained to a certain extent in that $\mathrm{CO}$ and $\mathrm{HC}$ are mainly generated by cars and taxis, which accounted for a large proportion of the traffic volume.

Consequently, the mean EFs of the mixed vehicles in Xi' an, China, were $0.006 \pm 0.005,1.097 \pm 0.398,0.159 \pm 0.092$, $0.179 \pm 0.089$, and $0.317 \pm 0.172 \mathrm{~g} \cdot \mathrm{veh}^{-1} \cdot \mathrm{km}^{-1}$ for $\mathrm{PM}_{2.5}, \mathrm{CO}$, $\mathrm{NO}_{X}, \mathrm{HC}$, and VOCs, respectively. On the basis of linear regression, the EFs of cars which accounted for nearly $80 \%$ of the total fleet and taxis which were the second highest at $14 \%$ were calculated as shown in Table 4 during the daytime except night sampling period. The taxis had higher EFs than those of the cars for all pollutants. The EF of CO for the taxis was only slightly higher than that for the cars (1.1 times), while the other pollutants between them were dramatically different, particularly $\mathrm{PM}_{2.5}$ and $\mathrm{NO}_{X}$; the taxi EFs were 10 times and 7 times those of the cars, respectively. EFs of the taxis were higher than the cars perhaps because of the high fuel consumption and large changes in speed among taxis, as well as the tighter control of tail gas and the better vehicle condition of cars compared to that of taxis. The continuous operation of taxis will result in greater losses, which will lead to high pollutant emissions and thus an increase in the EFs of the pollutants. Moreover, the proportion of cars exceeds $80 \%$, which is much greater than that of taxis and may result in lower EFs than the actual values. 


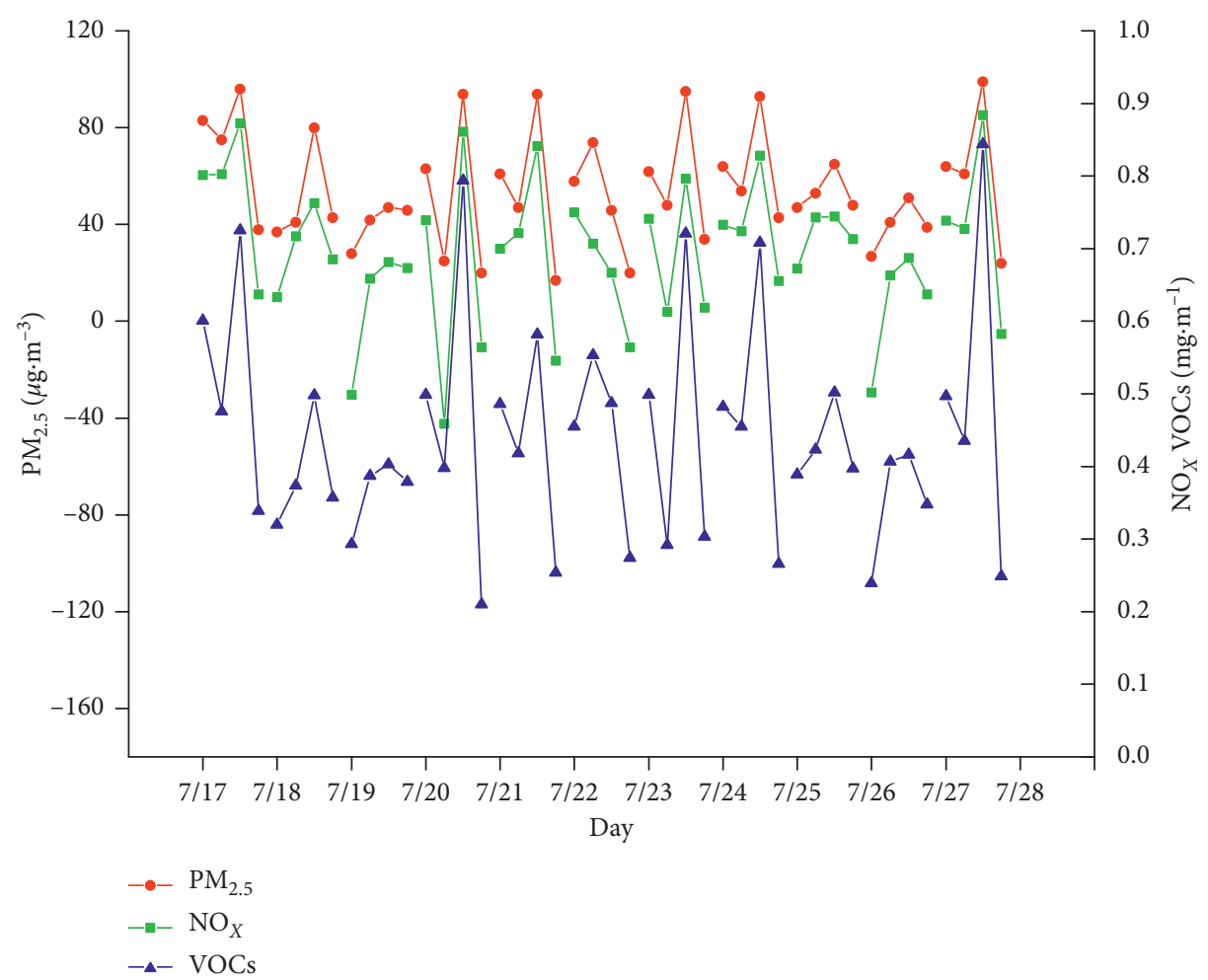

(a)

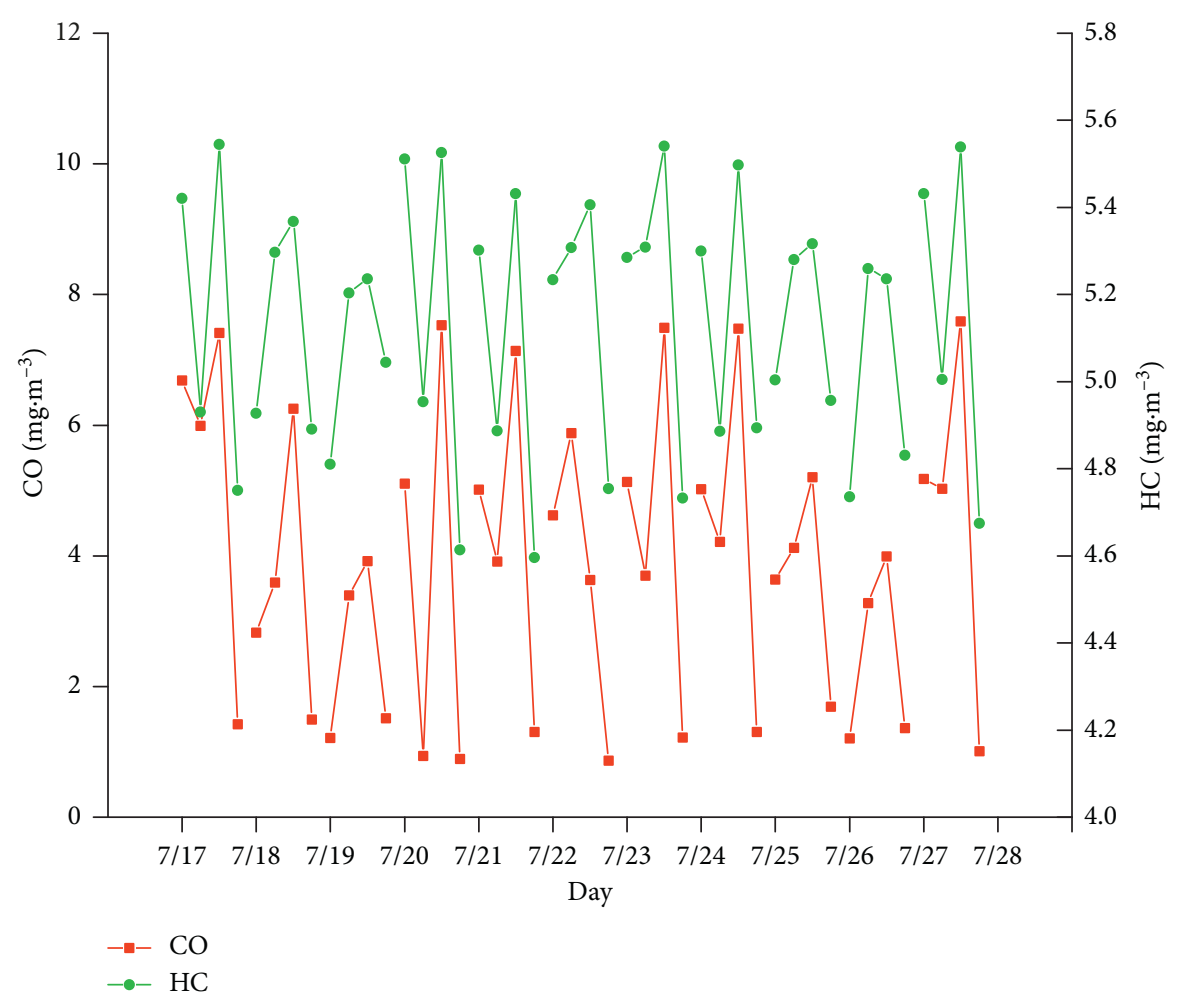

(b)

FIgURE 3: Diurnal variations in five pollutants at site 2 during the sampling period. (a) Diurnal variations in $\mathrm{PM}_{2.5}$ (left axes) and $\mathrm{NO}_{X}$ and VOCs (right axes) for 11 days. (b) Diurnal variations in CO (left axes) and HC (right axes) for 11 days.

A comparison of the EFs among this study and other studies is shown in Table 4. The calculated EFs were the highest in the North Ring Road Tunnel in Xi'an [25], in which the $\mathrm{CO}, \mathrm{NO}_{X}$, and $\mathrm{HC}$ EFs were approximately 20, 25, and 30 times higher than those of the current study, respectively. This could be attributed to the model year 1996 


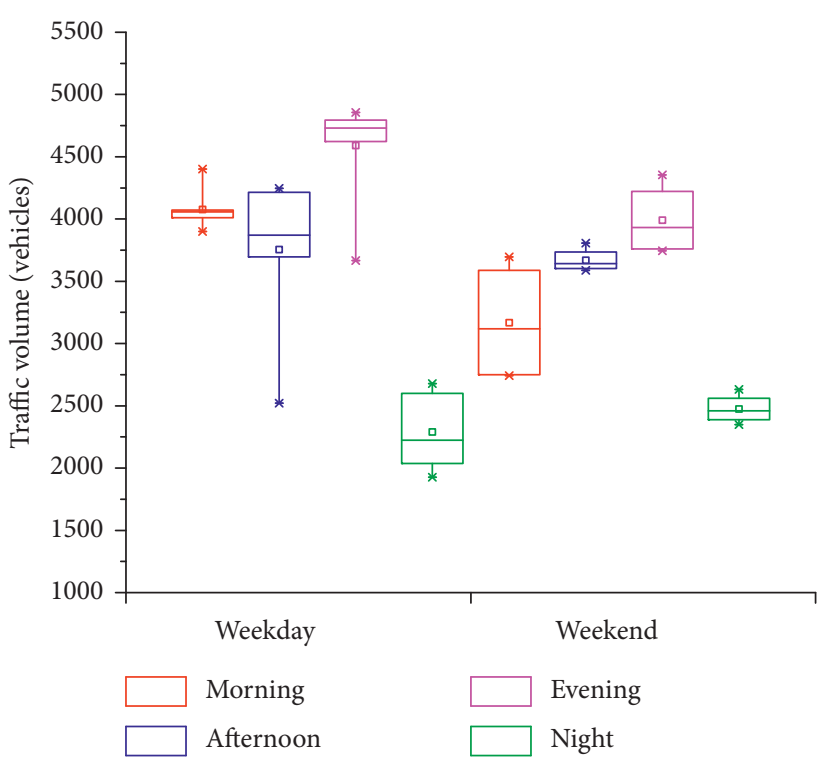

(a)

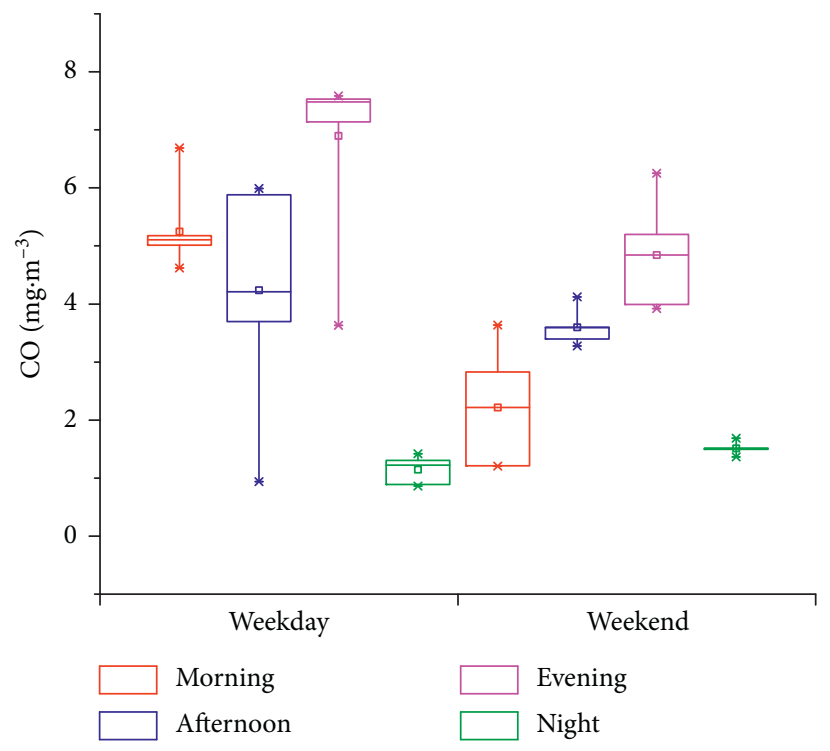

(c)

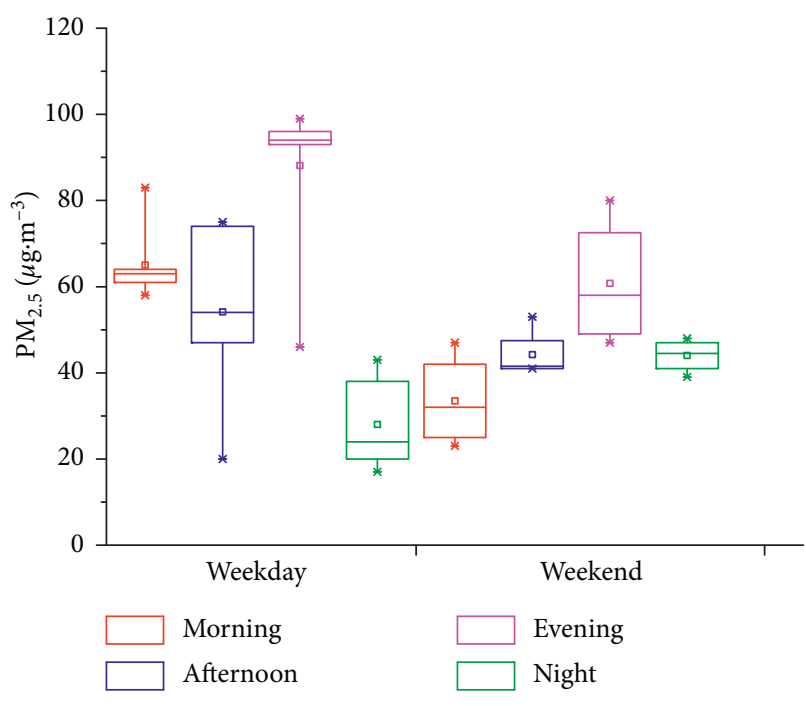

(b)

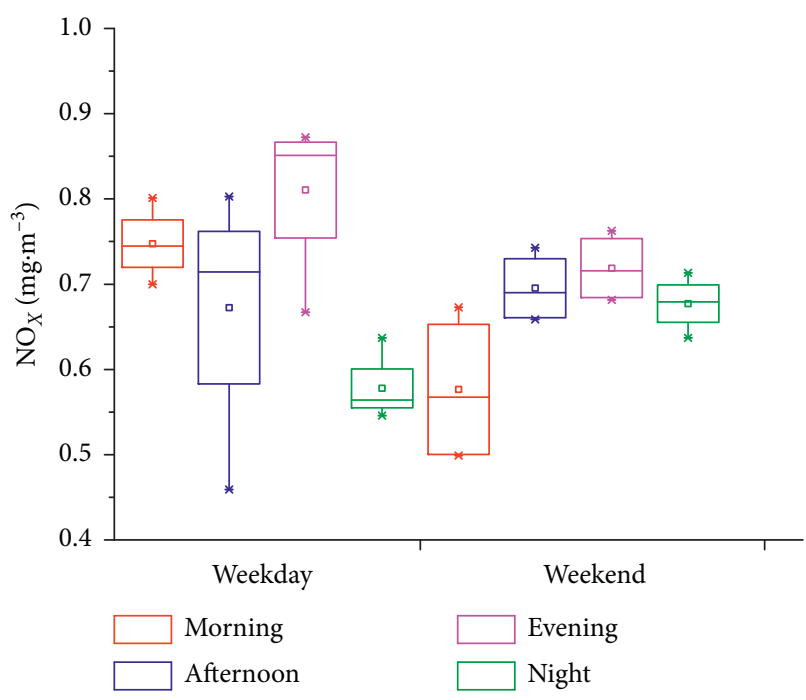

(d)

Figure 4: Continued. 


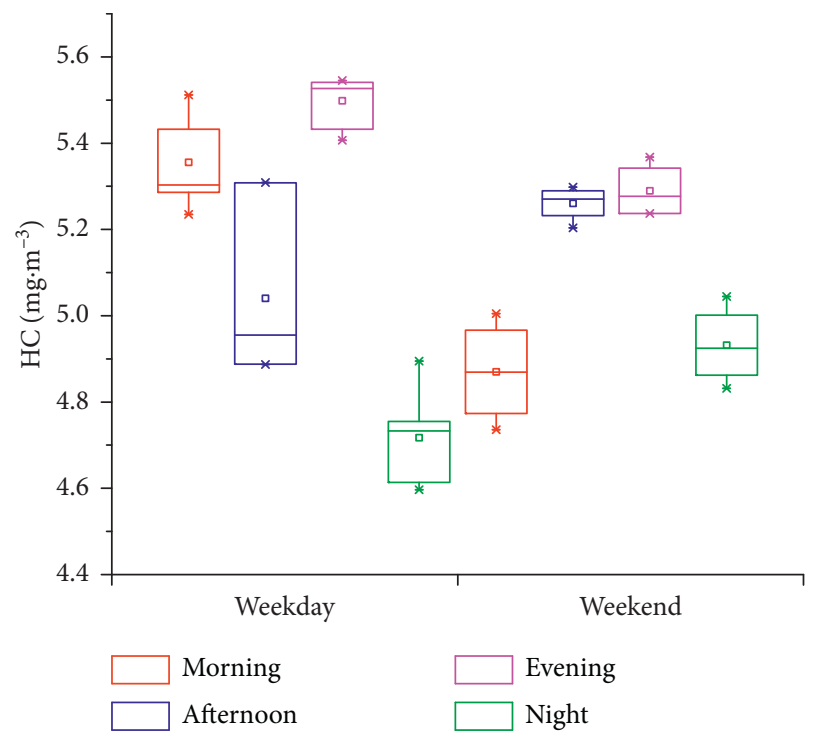

(e)

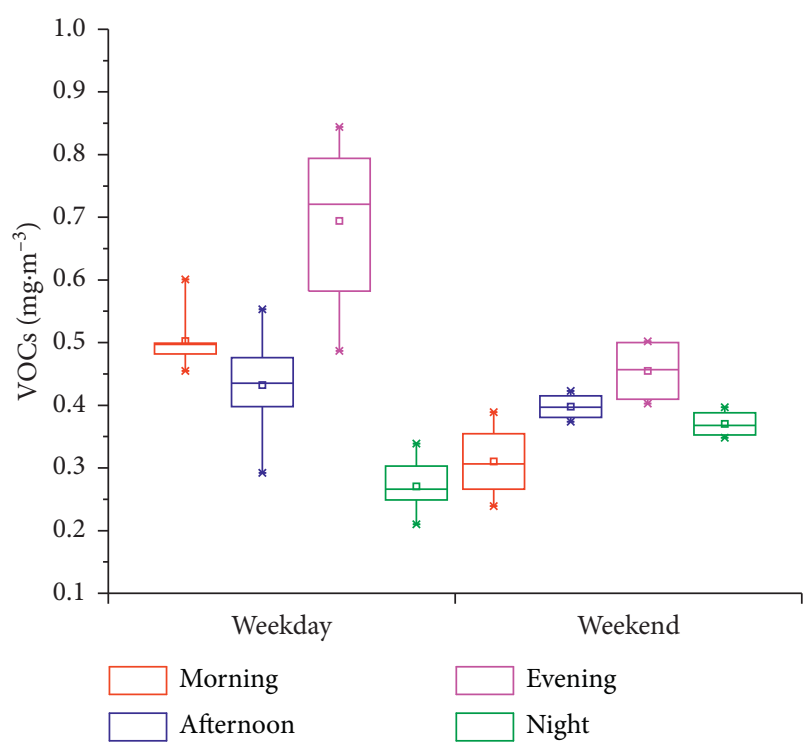

(f)

FIGURE 4: Weekday-weekend pattern of pollutant emissions. The comparison of weekday and weekend traffic volume (a), $\mathrm{PM} 2.5$ (b), $\mathrm{CO}$ (c), $\mathrm{NO}_{X}(\mathrm{~d})$, $\mathrm{HC}(\mathrm{e})$, and VOCs (f) during the four sampling periods.

TABLE 3: Average EFs $\left(\mathrm{g} \cdot \mathrm{veh}^{-1} \cdot \mathrm{km}^{-1}\right)$ during different sampling periods.

\begin{tabular}{lccccr}
\hline Species & Morning & Afternoon & Evening & Night & Range \\
\hline $\mathrm{PM}_{2.5}$ & $0.006 \pm 0.004$ & $0.005 \pm 0.003$ & $0.06 \pm 0.004$ & $0.011 \pm 0.010$ & $0.001 \sim 0.018$ \\
$\mathrm{CO}$ & $1.042 \pm 0.152$ & $1.041 \pm 0.472$ & $1.260 \pm 0.678$ & $1.243 \pm 0.197$ & $0.586 \sim 2.271$ \\
$\mathrm{NO}_{X}$ & $0.122 \pm 0.078$ & $0.137 \pm 0.067$ & $0.143 \pm 0.070$ & $0.236 \pm 0.115$ & $0.052 \sim 0.438$ \\
$\mathrm{HC}$ & $0.153 \pm 0.066$ & $0.135 \pm 0.030$ & $0.213 \pm 0.145$ & $0.224 \pm 0.101$ & $0.073 \sim 0.379$ \\
VOCs & $0.265 \pm 0.077$ & $0.199 \pm 0.050$ & $0.365 \pm 0.092$ & $0.607 \pm 0.184$ & $0.125 \sim 0.868$ \\
\hline
\end{tabular}

when the fleets included both passenger cars and GVs during the day as well as the quality of the fuels, which was poor, and the emission standards, which were low. With the strict requirements of today's emission standards and improvements in vehicle technology, emission conditions have significantly changed EFs of $\mathrm{CO}$ and $\mathrm{HC}$ in the Zhujiang Tunnel [34] which had a considerable decreasing trend from 1999 to 2004 of four-fifths [30]. Although the Clem Jones Tunnel in Australia [35] and the Yingpan Road Tunnel in Changsha [31] had lower EFs than most of the other studied tunnels, they were slightly higher than those of this study. $\mathrm{NO}_{X}$ and VOCs in the Shing Mun Tunnel [29] and Taipei Tunnel [36] were one-half of those in this study. For the type of vehicle, cars and taxi EFs in the Xianyue Mountain Tunnel [37] and Zhujiang Tunnel [38] were much higher because of terrain and gradient factors as well as old emission standards in China. In general, the EFs in the present study were lower than those of most other studies. It was found that the limitation of GVs is an effective policy in reducing vehicle emissions.

\section{Conclusions}

On-road traffic conditions, meteorological parameters, and emissions of $\mathrm{PM}_{2.5}, \mathrm{CO}, \mathrm{NO}_{X}, \mathrm{HC}$, and VOCs were measured in the Wenchang Gate-Peace Gate Tunnel in Xi'an from July 17 to July 27, 2015. The EFs of the different pollutants for the total fleet during distinct sampling periods were derived using the mass balance model. Moreover, linear regression analysis was adopted to calculate the EFs for the cars ( $80 \%$ of the total vehicles) and the taxis $(16 \%)$. For mixed traffic, a weekday-weekend pattern in which the values during the weekdays were higher than those during weekends was found in the pollutant emissions. Similarly, the evening transit had higher emissions than during other times, which was observed in the diurnal variations. $\mathrm{PM}_{2.5}$ emissions correlated well with $\mathrm{NO}_{X}$, while $\mathrm{HC}$ emissions had a high correlation with $\mathrm{CO}$. The EFs during the night were the highest because of the GVs, and the average EFs for the five pollutants in this study were lower than those of most of the other literature studies. This is probably the result of stricter emission standards and the new emission-reduced technology of vehicles. In addition, the EFs for the taxis were significantly higher than those of the cars, showing a reasonable agreement with other studies. This study not only presents the latest vehicle emission levels in Xi'an but also provides a sound reference for traffic pollutant assessments and policymaking for the government. Further study can focus on sampling more periods in which diesel trucks are allowed in the tunnel such that light-duty and heavy-duty emission factors can be determined, and one can consider the impact of trucks on the EFs of cars and taxis at night. 
TABLE 4: A comparison of the EFs $\left(\mathrm{g} \cdot \mathrm{veh}^{-1} \cdot \mathrm{km}^{-1}\right)$ among this study and other studies.

\begin{tabular}{|c|c|c|c|c|c|c|c|c|c|c|}
\hline Tunnel & City/Country & $\begin{array}{l}\text { Test } \\
\text { year }\end{array}$ & $\begin{array}{l}\text { Average } \\
\text { vehicle } \\
\text { speed } \\
\left(\mathrm{km} \cdot \mathrm{h}^{-1}\right)\end{array}$ & Vehicle type & $\mathrm{PM}_{2.5}$ & $\mathrm{CO}$ & $\mathrm{NO}_{X}$ & $\mathrm{HC}$ & VOCs & References \\
\hline $\begin{array}{l}\text { Clem Jones } \\
\text { Tunnel }\end{array}$ & $\begin{array}{l}\text { Brisbane, } \\
\text { Australia }\end{array}$ & 2014 & 80 & Light-duty & $\begin{array}{c}0.015 \pm \\
0.002\end{array}$ & $1.370 \pm 0.079$ & $0.519 \pm 0.036$ & & & {$[35]$} \\
\hline Zhujiang Tunnel & $\begin{array}{l}\text { Guangzhou, } \\
\text { China }\end{array}$ & 2014 & $20-47$ & Total fleet & & $3.096 \pm 0.680$ & $1.286 \pm 0.204$ & $\begin{array}{c}0.448 \pm \\
0.038\end{array}$ & & {$[32]$} \\
\hline $\begin{array}{l}\text { Yingpan Road } \\
\text { Tunnel }\end{array}$ & $\begin{array}{l}\text { Changsha, } \\
\text { China }\end{array}$ & 2013 & 30 & $\begin{array}{c}97.3 \% \\
\text { gasoline }\end{array}$ & & $\begin{array}{c}0.745 \pm \\
0.561 \sim 6.050 \pm \\
5.940\end{array}$ & $\begin{array}{c}0.121 \pm \\
0.022 \sim 0.818 \pm \\
0.755\end{array}$ & & & {$[33]$} \\
\hline $\begin{array}{l}\text { Van Nuys } \\
\text { Tunnel }\end{array}$ & $\begin{array}{c}\text { Nuys, } \\
\text { California }\end{array}$ & 2010 & 42.4 & $\begin{array}{c}97 \% \\
\text { gasoline }\end{array}$ & & $21.300 \pm 3.700$ & $3.000 \pm 0.600$ & $\begin{array}{c}2.300 \pm \\
0.300\end{array}$ & & [39] \\
\hline $\begin{array}{l}\text { Loma Larga } \\
\text { Tunnel }\end{array}$ & $\begin{array}{l}\text { Monterrey, } \\
\text { Mexico }\end{array}$ & 2009 & $42-76$ & $\begin{array}{c}97 \% \\
\text { gasoline }\end{array}$ & $\begin{array}{l}\text { Uphill: } \\
0.013 \pm \\
0.006\end{array}$ & $11.800 \pm 3.880$ & $0.130 \pm 0.100$ & $\begin{array}{c}1.540 \pm \\
0.080\end{array}$ & & [29] \\
\hline $\begin{array}{l}\text { Xianyue } \\
\text { Mountain } \\
\text { Tunnel }\end{array}$ & $\begin{array}{l}\text { Xiamen, } \\
\text { China }\end{array}$ & 2005 & 47.45 & $\begin{array}{l}\text { Car } \\
\text { Taxi }\end{array}$ & & $\begin{array}{l}14.200 \\
19.700\end{array}$ & $\begin{array}{l}2.210 \\
4.150\end{array}$ & $\begin{array}{l}0.670 \\
0.960\end{array}$ & & {$[37]$} \\
\hline $\begin{array}{l}\text { Shing Mun } \\
\text { Tunnel }\end{array}$ & $\begin{array}{l}\text { Hong Kong, } \\
\text { China }\end{array}$ & 2004 & 65 & $\begin{array}{c}50 \% \\
\text { gasoline }\end{array}$ & $\begin{array}{c}0.131 \pm \\
0.037\end{array}$ & $1.845 \pm 0.434$ & $0.878 \pm 0.308$ & $\begin{array}{c}0.115 \pm \\
0.030\end{array}$ & 0.115 & {$[31,40]$} \\
\hline Taipei Tunnel & $\begin{array}{l}\text { Taipei, } \\
\text { Taiwan }\end{array}$ & 2002 & & Total fleet & & $3.640 \pm 0.260$ & $0.900 \pm 0.180$ & $\begin{array}{c}0.440 \pm \\
0.060\end{array}$ & 0.240 & {$[36]$} \\
\hline Zhujiang Tunnel & $\begin{array}{c}\text { Guangzhou, } \\
\text { China }\end{array}$ & 1999 & 49 & $\begin{array}{l}\text { Total fleet } \\
\text { Car } \\
\text { Taxi }\end{array}$ & & $\begin{array}{c}15.400 \pm 6.630 \\
12.510 \\
16.640\end{array}$ & $\begin{array}{c}1.380 \pm 0.480 \\
0.420 \\
2.000\end{array}$ & $\begin{array}{c}1.860 \pm \\
1.760 \\
4.700 \\
0.540\end{array}$ & $\begin{array}{c}0.520 \pm \\
0.070\end{array}$ & {$[34,38]$} \\
\hline $\begin{array}{l}\text { North Ring } \\
\text { Road Tunnel }\end{array}$ & Xi'an, China & 1996 & 42.2 & $\begin{array}{l}66.7 \% \\
\text { gasoline }\end{array}$ & & $\begin{array}{c}33.279 \pm \\
12.158\end{array}$ & $4.061 \pm 1.981$ & $\begin{array}{c}3.577 \pm \\
1.820\end{array}$ & & [27] \\
\hline $\begin{array}{l}\text { Caldecott } \\
\text { Tunnel }\end{array}$ & $\begin{array}{l}\text { San } \\
\text { Francisco, } \\
\text { USA }\end{array}$ & 1997 & & $\begin{array}{l}\text { Light-duty } \\
\text { Heavy-duty }\end{array}$ & $\begin{array}{c}0.006 \\
0.430 \pm \\
0.079\end{array}$ & & & & & {$[41]$} \\
\hline $\begin{array}{l}\text { Wenchang Gate- } \\
\text { Peace Gate } \\
\text { Tunnel (this } \\
\text { study) }\end{array}$ & Xi'an, China & 2015 & 33.18 & $\begin{array}{l}\text { Total fleet } \\
\text { Car } \\
\text { Taxi }\end{array}$ & $\begin{array}{c}0.006 \pm \\
0.005 \\
0.004 \\
0.038\end{array}$ & $\begin{array}{c}1.097 \pm 0.398 \\
1.085 \\
1.167\end{array}$ & $\begin{array}{c}0.159 \pm 0.092 \\
0.078 \\
0.582\end{array}$ & $\begin{array}{c}0.179 \pm \\
0.089 \\
0.123 \\
0.442\end{array}$ & $\begin{array}{c}0.317 \pm \\
0.172 \\
0.060 \\
1.650\end{array}$ & \\
\hline
\end{tabular}

\section{Data Availability}

The data in this study were tested and provided by the Xi' an Institute of Environmental Science, only for use by the collaborators, and they are not allowed to be disseminated to the public.

\section{Conflicts of Interest}

The authors declare that there are no conflicts of interest regarding the publication of this article.

\section{Acknowledgments}

This work was supported by the National Natural Science Foundation of China (Grant no. 51178055) and the Technology Project of Shaanxi Transportation Department (Grant no. 15-39R). It was also supported by the Special Fund for Basic Scientific Research of Central Colleges of Chang'an University (Grant no. 300102218409). The authors gratefully thank the Xi'an Institute of Environmental Science for their support.

\section{References}

[1] M. Campen, S. Robertson, A. Lund, J. Lucero, and J. McDonald, "Engine exhaust particulate and gas phase contributions to vascular toxicity," Inhalation Toxicology, vol. 26, no. 6, pp. 353-360, 2014.

[2] S. C. Anenberg, J. Miller, R. Minjares et al., "Impacts and mitigation of excess diesel-related $\mathrm{NO}_{x}$ emissions in 11 major vehicle markets," Nature, vol. 545, no. 7655, pp. 467-471, 2017.

[3] R. J. Huang, Y. Zhang, C. Bozzetti et al., "High secondary aerosol contribution to particulate pollution during haze events in China," Nature, vol. 514, no. 7521, pp. 218-222, 2014.

[4] R. Saini, A. Taneja, and P. Singh, "Surface ozone scenario and air quality in the north-central part of India," Journal of Environmental Sciences, vol. 59, pp. 72-79, 2017.

[5] J. L. Schnell and M. J. Prather, "Co-occurrence of extremes in surface ozone, particulate matter, and temperature over eastern North America," Proceedings of the National Academy of Sciences of the United States of America, vol. 114, no. 11, pp. 2854-2859, 2017.

[6] M. Dastoorpoor, E. Idani, N. Khanjani, G. Goudarzi, and A. Bahrampour, "Relationship between air pollution, weather, 
traffic, and traffic-related mortality," Trauma Monthly, vol. 21, no. 4, article e37585, 2016.

[7] Y. Hu, L. Yao, Z. Cheng, and Y. Wang, "Long-term atmospheric visibility trends in megacities of China, India and the United States," Environmental Research, vol. 159, pp. 466-473, 2017.

[8] P. Hystad, P. A. Demers, K. C. Johnson et al., "Spatiotemporal air pollution exposure assessment for a Canadian populationbased lung cancer case-control study," Environmental Health, vol. 11, p. 22, 2012.

[9] S. Zhao, Y. Yu, N. Liu, J. He, and J. Chen, "Effect of traffic restriction on atmospheric particle concentrations and their size distributions in urban Lanzhou, Northwestern China," Journal of Environmental Sciences, vol. 26, no. 2, pp. 362-370, 2014.

[10] F. Palmgren, R. Berkowicz, A. Ziv, and O. Hertel, “Actual car fleet emissions estimated from urban air quality measurements and street pollution models," Science of the Total Environment, vol. 235, no. 1-3, pp. 101-109, 1999.

[11] C. A. Colberg, B. Tona, G. Catone et al., "Statistical analysis of the vehicle pollutant emissions derived from several European road tunnel studies," Atmospheric Environment, vol. 39, no. 13, pp. 2499-2511, 2005.

[12] R. Joumard, J. Laurikko, T. Le Han et al., "Accuracy of exhaust emission factor measurements on chassis dynamometer," Journal of the Air and Waste Management Association, vol. 59, no. 6, pp. 695-703, 2009.

[13] P. Brimblecombe, T. Townsend, C. F. Lau et al., “Throughtunnel estimates of vehicle fleet emission factors," Atmospheric Environment, vol. 123, pp. 180-189, 2015.

[14] T. R. Dallmann, S. J. DeMartini, T. W. Kirchstetter et al., "Onroad measurement of gas and particle phase pollutant emission factors for individual heavy-duty diesel trucks," Environmental Science and Technology, vol. 46, no. 15, pp. 8511-8518, 2012.

[15] T. D. Durbin, K. Johnson, D. R. Cocker et al., "Evaluation and comparison of portable emissions measurement systems and federal reference methods for emissions from a back-up generator and a diesel truck operated on a chassis dynamometer," Environmental Science and Technology, vol. 41, no. 17, pp. 6199-6204, 2007.

[16] K. S. Nesamani, "Estimation of automobile emissions and control strategies in India," Science of the Total Environment, vol. 408, no. 8, pp. 1800-1811, 2010.

[17] R. Smit and J. Bluett, "A new method to compare vehicle emissions measured by remote sensing and laboratory testing: high-emitters and potential implications for emission inventories," Science of the Total Environment, vol. 409, no. 13, pp. 2626-2634, 2011.

[18] M. D. Geller, S. B. Sardar, H. Phuleria, P. M. Fine, and C. Sioutas, "Measurements of particle number and mass concentrations and size distributions in a tunnel environment," Environmental Science and Technology, vol. 39, no. 22, pp. 8653-8663, 2005.

[19] T. Liu, X. Wang, B. Wang et al., "Emission factor of ammonia (NH3) from on-road vehicles in China: tunnel tests in urban Guangzhou," Environmental Research Letters, vol. 9, no. 6, article 064027, 2014.

[20] L. D. Martins, M. F. Andrade, E. D. Freitas et al., "Emission factors for gas-powered vehicles traveling through road tunnels in Sao Paulo, Brazil," Environmental Science and Technology, vol. 40, no. 21, pp. 6722-6729, 2006.

[21] Q. Li, C. Chen, Y. Deng et al., "Influence of traffic force on pollutant dispersion of $\mathrm{CO}, \mathrm{NO}$ and particle matter $\left(\mathrm{PM}_{2.5}\right)$ measured in an urban tunnel in Changsha, China," Tunnelling and Underground Space Technology, vol. 49, pp. 400-407, 2015.

[22] C. Johansson, M. Norman, and L. Burman, "Road traffic emission factors for heavy metals," Atmospheric Environment, vol. 43, no. 31, pp. 4681-4688, 2009.

[23] R. Smit, L. Ntziachristos, and P. Boulter, "Validation of road vehicle and traffic emission models-a review and metaanalysis," Atmospheric Environment, vol. 44, no. 25, pp. 2943-2953, 2010.

[24] H. Abou-Senna, E. Radwan, K. Westerlund, and C. D. Cooper, "Using a traffic simulation model (VISSIM) with an emissions model (MOVES) to predict emissions from vehicles on a limited-access highway," Journal of the Air and Waste Management Association, vol. 63, no. 7, pp. 819-831, 2013.

[25] R. Kumari, A. K. Attri, L. I. Panis, and B. R. Gurjar, "Emission estimates of particulate matter and heavy metals from mobile sources in Delhi (India)," Journal of Environmental Science and Engineering, vol. 55, no. 2, pp. 127-142, 2013.

[26] A. P. Grieshop, E. M. Lipsky, N. J. Pekney, S. Takahama, and A. L. Robinson, "Fine particle emission factors from vehicles in a highway tunnel: effects of fleet composition and season," Atmospheric Environment, vol. 40, pp. 287-298, 2006.

[27] S. X. Deng, J. Chen, and B. C. Li, "Emission factors of CO, HC and $\mathrm{NO}_{X}$ from motor vehicles on urban main road in China," China Environmental Science, vol. 20, pp. 82-85, 2000.

[28] T. R. Dallmann, T. W. Kirchstetter, S. J. DeMartini, and R. A. Harley, "Quantifying on-road emissions from gasolinepowered motor vehicles: accounting for the presence of medium- and heavy-duty diesel trucks," Environmental Science and Technology, vol. 47, no. 23, pp. 13873-13881, 2013.

[29] Y. Mancilla and A. Mendoza, "A tunnel study to characterize $\mathrm{PM}_{2.5}$ emissions from gasoline-powered vehicles in Monterrey, Mexico," Atmospheric Environment, vol. 59, pp. 449460, 2012.

[30] W. R. Pierson, A. W. Gertler, N. F. Robinson et al., "Realworld automotive emissions-summary of studies in the Fort McHenry and Tuscarora mountain tunnels," Atmospheric Environment, vol. 30, no. 12, pp. 2233-2256, 1996.

[31] Y. Cheng, S. C. Lee, K. F. Ho, and P. K. K. Louie, "On-road particulate matter $\left(\mathrm{PM}_{2.5}\right)$ and gaseous emissions in the Shing Mun Tunnel, Hong Kong," Atmospheric Environment, vol. 40, no. 23, pp. 4235-4245, 2006.

[32] Y. Zhang, X. Wang, G. Li et al., "Emission factors of fine particles, carbonaceous aerosols and traces gases from road vehicles: recent tests in an urban tunnel in the Pearl River Delta, China," Atmospheric Environment, vol. 122, pp. 876884, 2015.

[33] Y. Deng, C. Chen, Q. Li et al., "Measurements of real-world vehicle $\mathrm{CO}$ and $\mathrm{NO}_{x}$ fleet average emissions in urban tunnels of two cities in China," Atmospheric Environment, vol. 122, pp. 417-426, 2015.

[34] B. G. Wang, Y. H. Zhang, C. J. Zhu, K. H. Yu, L. Y. Chen, and Z. Y. Chen, "A study on city motor vehicle emission factors by tunnel test,” Environmental Science, vol. 22, no. 2, pp. 55-59, 2001.

[35] R. Smit, P. Kingston, D. H. Wainwright, and R. Tooker, “A tunnel study to validate motor vehicle emission prediction software in Australia," Atmospheric Environment, vol. 151, pp. 188-199, 2017.

[36] M.-Y. Hwa, C.-C. Hsieh, T.-C. Wu, and L.-F. W. Chang, "Real-world vehicle emissions and VOCs profile in the Taipei tunnel located at Taiwan Taipei area," Atmospheric Environment, vol. 36, no. 12, pp. 1993-2002, 2002. 
[37] J. Wang, "Research on the discharging factor of vehicles in Xiamen," Modern Scientific Instruments, vol. 6, pp. 61-64, 2005.

[38] L. L. Fu, M. Shao, Y. Liu, Y. Liu, S. H. Lu, and D. G. Tang, "Tunnel experimental study on the emission factors of volatile organic compounds (VOCs) from vehicles," Acta Scientiae Circumstantiae, vol. 25, no. 7, pp. 879-885, 2005.

[39] E. M. Fujita, D. E. Campbell, B. Zielinska et al., "Comparison of the MOVES2010a, MOBILE6.2, and EMFAC2007 mobile source emission models with on-road traffic tunnel and remote sensing measurements," Journal of the Air and Waste Management Association, vol. 62, no. 10, pp. 1134-1149, 2012.

[40] K. F. Ho, S. C. Lee, W. K. Ho et al., "Vehicular emission of volatile organic compounds (VOCs) from a tunnel study in Hong Kong," Atmospheric Chemistry and Physics, vol. 9, no. 19, pp. 7491-7504, 2009.

[41] J. O. Allen, P. R. Mayo, L. S. Hughes, L. G. Salmon, and G. R. Cass, "Emissions of size-segregated aerosols from onroad vehicles in the Caldecott tunnel," Environmental Science and Technology, vol. 35, no. 21, pp. 4189-4197, 2001. 

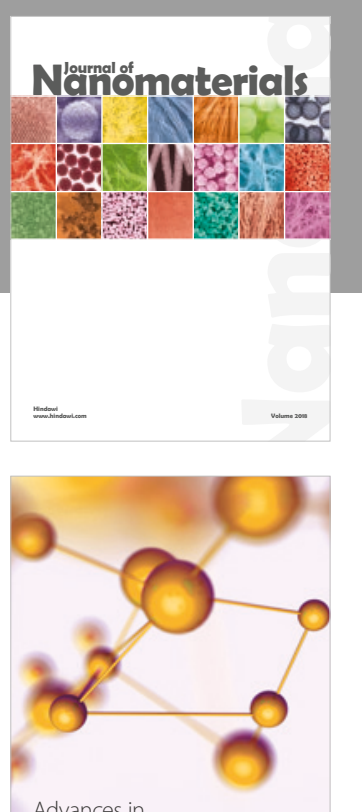

Physical Chemistry
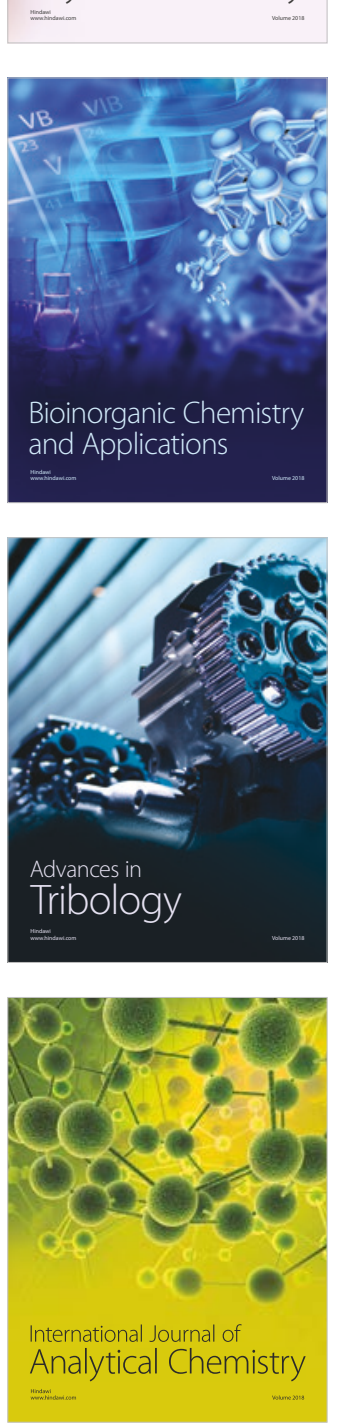

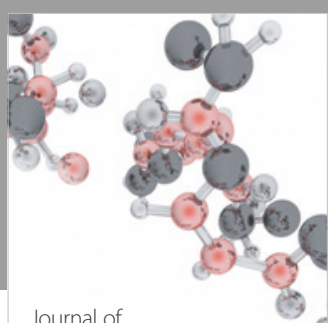

Analytical Methods

in Chemistry

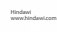

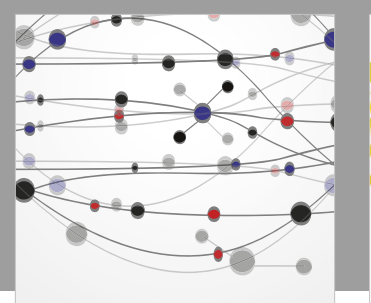

The Scientific World Journal

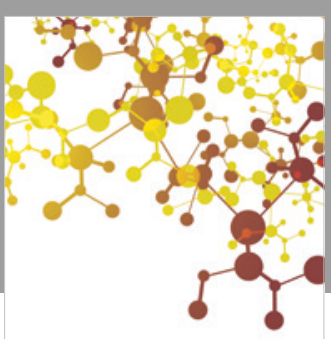

Journal of

Applied Chemistry
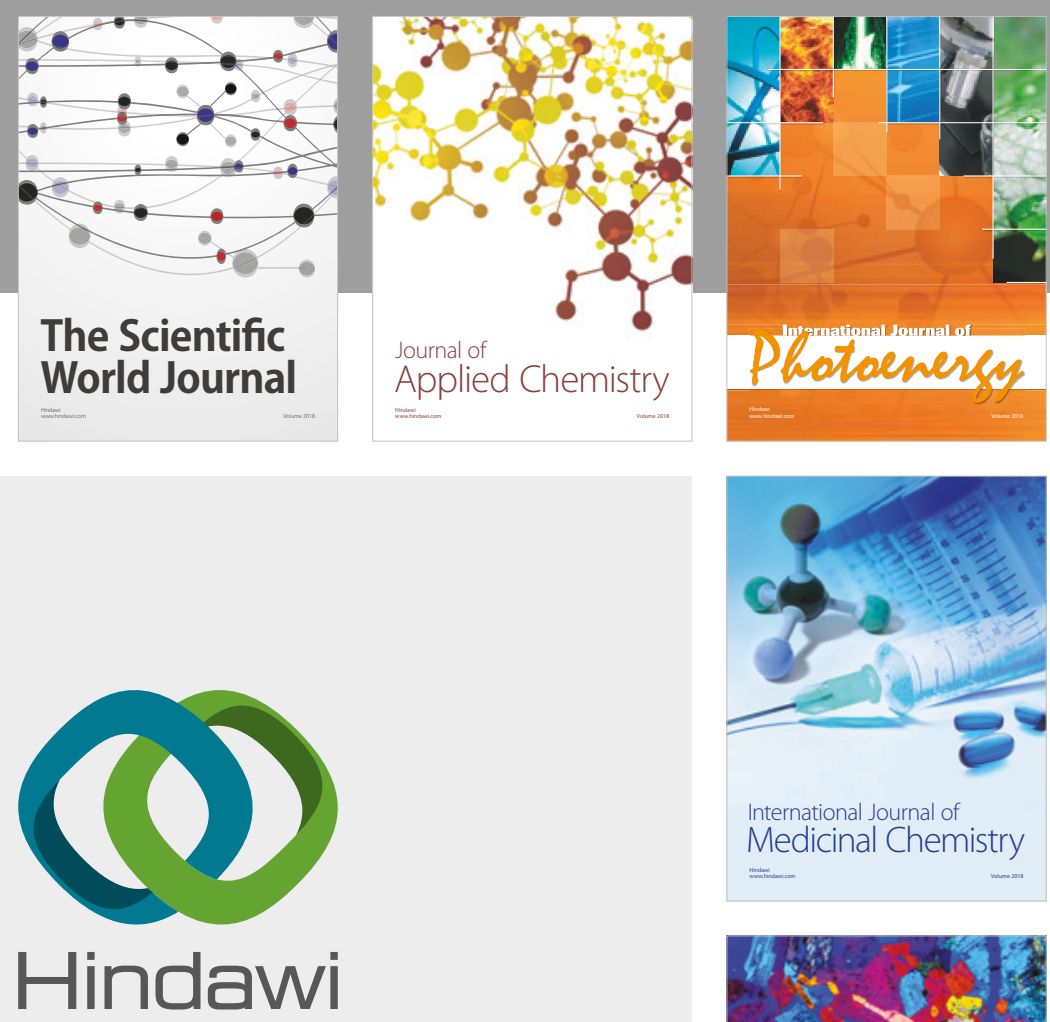

Submit your manuscripts at

www.hindawi.com
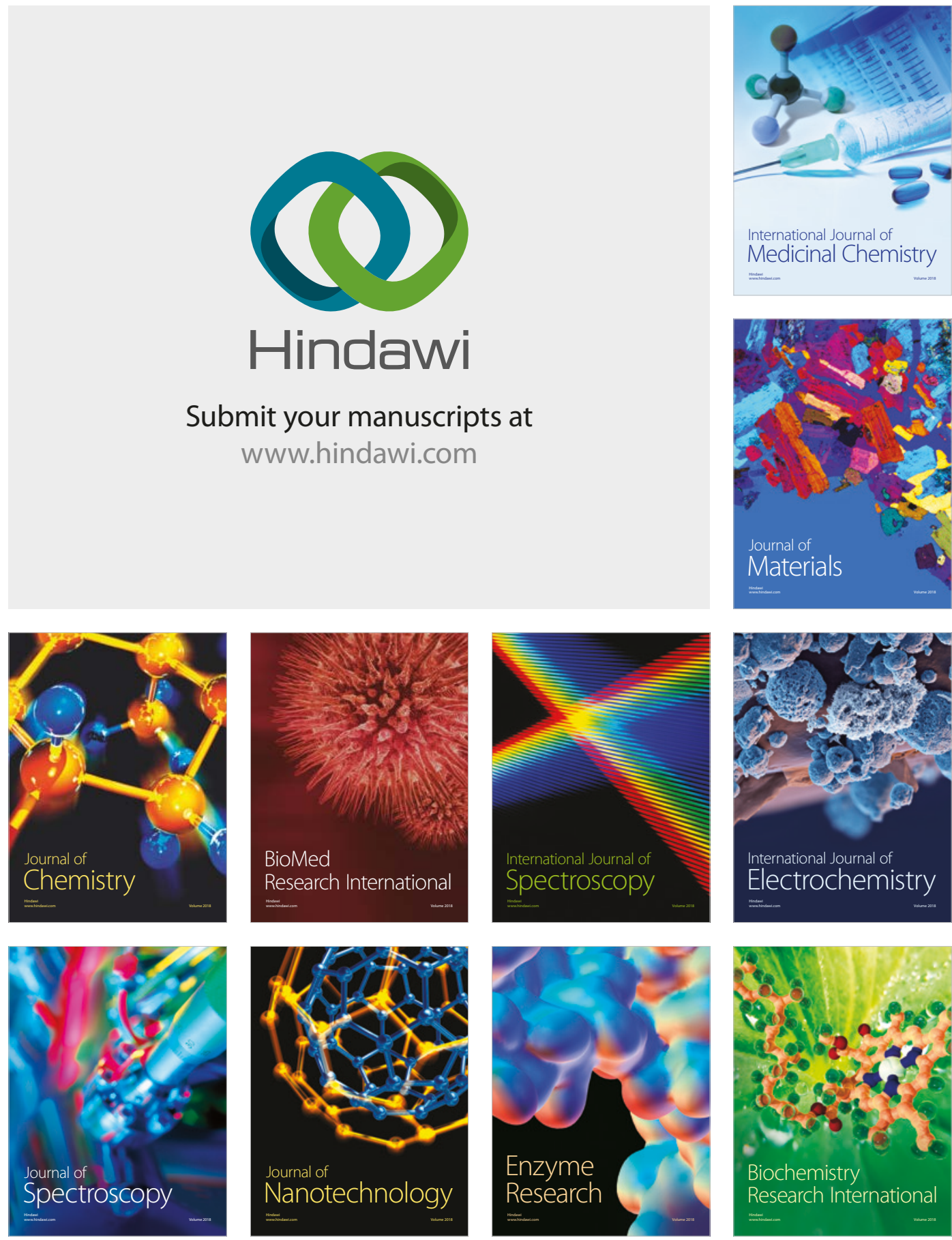
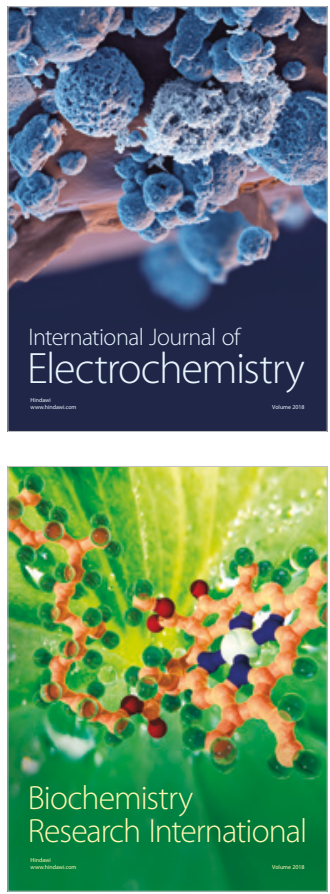